Markó Alexandra ${ }^{\mathrm{I}, 2}$ - Csapó Tamás Gábor ${ }^{2,3}$ - Deme Andrea ${ }^{\mathrm{I}, 2}-$

Bartók Márton ${ }^{2}$ - Gráczi Tekla Etelka ${ }^{2,4}$

${ }^{1}$ ELTE Alkalmazott Nyelvészeti és Fonetikai Tanszék, ${ }^{2}$ MTA-ELTE „Lendület” Lingvális

Artikuláció Kutatócsoport, ${ }^{3}$ BME Távközlési és Médiainformatikai Tanszék,

${ }^{4} N y$ elvtudományi Intézet

marko.alexandra@btk.elte.hu.

csapot@tmit.bme.hu.

deme.andrea@btk.elte.hu.

bartokmarton@gmail.com.

graczi.tekla.etelka@nytud.hu

\title{
A MAGÁNHANGZÓK LINGVÁLIS KÉPZÉSI JEGYEINEK TANÍTÁSA AZ ARTIKULÁCIÓS TAPASZTALAT, A KUTATÁSI EREDMÉNYEK ÉS AZ ELMÉLETI KATEGÓRIÁK TÜKRÉBEN
}

\section{Bevezetés}

\subsection{A magánhangzók képzési jegyei és az elméleti kategóriák}

A magánhangzókat hagyományosan artikulációs és akusztikai tulajdonságok keverékével, artikulációs, akusztikai és percepciós alapon jellemezzük, a következők szerint. 1. Az állkapocsnyitás szöge / a nyelvállás foka (ti. a nyelv legmagasabb pontjának vagy a nyelvtestnek a függőleges helyzete): e szerint megkülönböztetünk zárt / felső nyelvállású és nyílt / legalsó nyelvállású hangzókat, valamint (elsősorban percepciós alapon) két köztes kategóriát, a középzárt/középső nyelvállású és középnyílt/alsó nyelvállású hangokét. 2. A nyelv vízszintes helyzete / elölség (ti. a nyelv legmagasabb pontjának vagy a nyelvtestnek a vízszintes helyzete): e szerint beszélünk elöl képzett, hátul képzett, illetve e kettő közötti, azaz mediális/centrális hangokról. 3. Az ajkak működése: e szerint léteznek ajakkerekítéses, valamint ajakréses/kerekítetlen magánhangzók. Ez a három jellemző adja meg a magánhangzó minőségét. Mindezekhez pedig azon nyelvekben, ahol nyelvi jelentősége van, negyedikként a hosszúság (kvantitás) fonológiai jegye is társul a jellemzésben, amelyet fonetikailag elsősorban a fizikai időtartammal szokás összekapcsolni. (Lásd pl. IPA 1999.) $\mathrm{Az}$ 1. és 2. magánhangzó-tulajdonság elsődlegesen vagy részint a nyelv mint beszédszerv helyzetével hozható összefüggésbe, ezekre együttesen lingvális képzési jegyekként utalunk.

A fent felsorolt sajátosságok hagyományosan és széles körben elfogadottak, az artikulációt alaposabban megfigyelve azonban egyes vélekedések szerint a magánhangzóképzés e „lingvális-orális modellje” (Esling 2005: 15) meglehetősen leegyszerűsítő, mivel 
artikulációs szempontból az általában csak "nyíltságként” hivatkozott dimenzió valójában alapvetően mást jelent az „elöl képzett”, és mást a „hátul képzett” hangok esetében. Míg az „elöl képzetteknél” valóban az állkapocs nyitásszöge tesz különbséget a kérdéses magánhangzó-kategóriák között, addig a „hátul képzetteknél” valójában nyelvemelésről (raising), és nyelvleszorításról (retraction) van szó rendre a „zárt” és „nyílt” „hátul képzett” magánhangzók artikulációjában (lásd Esling 2005: 23).

\subsection{A magánhangzók képzési jegyei és az elméleti kategóriák a tananyagban}

A közoktatásban 5. és 9. osztályban tananyag a magánhangzók képzése. A magánhangzók elöl- és hátul képzettségét, azaz a vízszintes nyelvhelyzet szerinti két csoportot magas és mély terminusokkal osztályozza mindkét tankönyv. (És bár az 5. osztályos tankönyv elmagyarázza, honnan származnak ezek a megnevezések, mégis: az egyetemi fonetika kurzusokon már rendre a felső nyelvállásúakat gondolják a diákok „magas”-nak, és az alsó nyelvállásúakat „mély”-nek.) A nyelv függőleges helyzetét tekintve az 5. osztályos tankönyv (Antalné-Raátz 2012) három, a 9. osztályos (Antalné-Raátz 2010) négy fokozatot különít el, nem magyarázza meg azonban, hogy mi ennek az eltérésnek az oka.

Az 5. osztályos tankönyv így fogalmaz: „Ha a nyelvedet előretolod, akkor kisebb lesz az üres rész a szádban, ilyenkor magas hangok fognak szólni. Amikor pedig hátrahúzod a nyelvedet, akkor a szájüreg nagyobb lesz, a hangok a nagyobb ürben mélyen fognak hallatszani. [...] A nyelv vízszintes mozgása szerint beszélhetünk elöl képzett, azaz magas és hátul képzett, azaz mély magánhangzókról. [...] A nyelv függőleges mozgása is befolyásolja a hangképzést. Eszerint megkülönböztetünk felső, középső és alsó nyelvállású magánhangzókat." (Antalné-Raátz 2012: 38). Mindehhez illusztrációként szolgál az 1. táblázat.

\begin{tabular}{|l|l|l|l|l|}
\hline \multirow{2}{*}{$\begin{array}{l}\text { A nyelv } \\
\text { mozgása szerint }\end{array}$} & \multicolumn{2}{|l|}{ Mély magánhangzók } & \multicolumn{2}{l|}{ Magas magánhangzók } \\
\cline { 2 - 5 } & Ajakkerekítéses & Ajakréses & Ajakkerekítéses & Ajakréses \\
\hline $\begin{array}{l}\text { Felső } \\
\text { nyelvállású }\end{array}$ & $u, \dot{u}$ & & $\ddot{u}, \ddot{u}$ & $i, i$ \\
\hline $\begin{array}{l}\text { Középső } \\
\text { nyelvállású }\end{array}$ & $o, \dot{o}$ & $\ddot{o}, \ddot{ }$ & $\dot{e}$ \\
\hline $\begin{array}{l}\text { Alsó } \\
\text { nyelvállású }\end{array}$ & $a$ & $a$ & & $e$ \\
\hline
\end{tabular}

1. táblázat: A magánhangzó-állomány bemutatása az 5. osztályos tankönyvben (Antalné-Raátz 2012: 39.)

A 9. osztályos tankönyvben ezt olvassuk: „A nyelv vízszintes mozgása szerint beszélhetünk elöl képzett, magas (palatális) és hátul képzett, mély (veláris) hangokról. A nyelv 
függőleges mozgása szerint elkülönítünk felső, középső, alsó és legalsó nyelvállású magánhangzókat.” (Antalné-Raátz 2010: 34). Ennek illusztrálására a tankönyv a 2. táblázatot hozza.

\begin{tabular}{|l|l|l|l|l|}
\hline & \multicolumn{2}{|l|}{ Mély magánhangzók } & \multicolumn{2}{l|}{ Magas magánhangzók } \\
\cline { 2 - 5 } & Ajakkerekítéses & Ajakréses & Ajakkerekítéses & Ajakréses \\
\hline $\begin{array}{l}\text { Felső } \\
\text { nyelvállású }\end{array}$ & $u, u ́$ & $\ddot{u}, u ̈$ & $i, i$ \\
\hline $\begin{array}{l}\text { Középső } \\
\text { nyelvállású }\end{array}$ & $o, o ́$ & $\ddot{o}, o ̈$ & $e ́$ \\
\hline $\begin{array}{l}\text { Alsó } \\
\text { nyelvállású }\end{array}$ & $a$ & & & $e$ \\
\hline $\begin{array}{l}\text { Legalsó } \\
\text { nyelvállású }\end{array}$ & & $a$ & & \\
\hline
\end{tabular}

2. táblázat: A magánhangzó-állomány bemutatása a 9. osztályos tankönyvben (Antalné-Raátz 2010: 34.)

Vegyük észre, hogy az á-t az IPA magánhangzó-táblázata (W1), valamint akusztikai elemzések (pl. Gósy-Bóna 2014) alapján elöl képzettnek kellene tekintenünk. Ez arra is rámutat, hogy ezek a táblázatos elrendezések (nemcsak a közoktatás tankönyveiben, hanem a hangtani szakirodalom túlnyomó részében is) valójában úgy operálnak artikulációs jellemzőkkel, hogy részben eleve a hangzók nyelvi viselkedéséből indulnak ki (melyek alapján az á-t valóban a nem elülső magánhangzók között tarthatjuk számon).

\subsection{A magánhangzók képzési jegyei és az artikulációs tapasztalat}

Mint ahogyan korábban láttuk, az artikulációs mozgások jóval komplexebbek annál, mint hogy pusztán a nyelv vízszintes és függőleges helyzete (és az ajakmüködés) dimenzióiban a fenti jegyekkel leírhatók lennének. A magánhangzók „képzési jegyei” nem önállóan, egymástól függetlenül valósulnak meg, illetve - mint láttuk - eltérő mozdulatokkal hozzuk létre az alsó/felső nyelvállást az elöl és a hátul képzett magánhangzók esetében; az elöl képzettek „elölsége” eltérő a különböző nyelvállásfokokon. Ezzel és a szájüregi tér alakjával összefüggésben az elülső és a hátulsó nyelvhelyzet közötti távolság nagyobb a felső nyelvállásfokon, mint az alsón. Természetesen a nyelv (és az állkapocs) emelkedése vagy süllyedése az ajakkerekítésbeli sajátosságokra is hatással van. Gondoljunk csak arra, hogy az ajakréses terminus mennyire más jelent (azaz mennyire másképpen néz ki az ajkak által alkotott rés) a felső nyelvállású /i/ és a legalsó nyelvállású /a/ esetében, vagy - hogy kerekítéses példát is hozzunk - a felső nyelvállású /u/ és a legalsó nyelvállású /o/ esetében. 
Az absztrakt képzési jegyek tanítása - különösen, ha ezeket olyan jegyeknek tartjuk, amelyek külön-külön egy az egyben megfeleltethetők artikulációs mozdulatoknak, képzőszervi helyzeteknek - egészen bizonyosan nehézséget okoz, hiszen az artikulációs és vizuális tapasztalat legalábbis részben ellentmond az absztrakt képzési jegyeknek. Mindehhez az is hozzájárul, hogy mivel a magánhangzók nem akadályhangok, beszéd közben nem kapunk jól megfigyelhető taktilis visszajelzéseket a magánhangzók létrehozását eredményező közelítés vagy szűkület létrejöttének helyéről, azaz a magánhangzó képzéshelyéről. Egyes magánhangzók képzésekor a nyelv érintkezhet a nem mozgatható artikulátorokkal - például a nyelvperem a felső nyelvállású magánhangzók esetében hozzáér a felső fogsorhoz (vö. Stevens 1998) - és ezek a szenzoros visszajelzések feltehetőleg hozzájárulnak ahhoz, hogy a beszélő az egyes magánhangzók ejtéséhez szükséges artikulációs beállításokat pontosan eltalálja, ez azonban megint csak magánhangzófüggő. Emellett a magánhangzók izolált ejtése statikus, így kinesztetikus információk sem segítik a magánhangzók képzéshelyének azonosítását, miközben a nyelv igen nagy variabilitással mozgatható és alakítható (Ashby 2011). Végül pedig a magánhangzók ejtése rendkívül variábilis is, hiszen a nyelv alakjának kontrollálása (a nyelv izmainak komplex szerkezete és a motoros ügyesség szükséges foka miatt) igen nehéz feladat.

Mindehhez az artikulációs komplexitáshoz hozzá kell vennünk azt is, hogy az artikulációs csatorna születéstől felnőttkorig jelentős változásokon megy keresztül, mind méreteit, mind arányait, mind pedig az egyes beszédképző szervek működési precizitását és összehangoltságát tekintve. A különböző életkori szakaszokban az érintett szervek méretbeli változása eltérő ütemű (Seikel et al. 2010). Az artikulációs csatorna a hangszalagoktól az ajkakig születéskor 6-8 cm hosszú, felnőttkorra a nőknél átlagosan 15, a férfiaknál $18 \mathrm{~cm}$ lesz. A nyelv mérete 7 éves korra a felnőtt méret mintegy 75\%-át éri el (Seikel et al. 2010). A gyermekkor és a pubertás között az ajkak, a nyelvperem és a nyelvhát, valamint a lágy szájpad nagyjából egységesen átlagosan 12\%-nyit növekszik (6 és 14\% közötti terjedelemmel), eközben a garatüreg hossza 22\%-nyit nyúlik. Hasonlóképpen, a pubertás és a felnőttkor között az artikulációs csatorna felső részei átlagosan 5\%-nyit nőnek (3 és 9\% között), míg a garatüreg hossza 25\%-nyit. A pubertás előtt a lányok és a fiúk artikulációs csatornájának hossza nem különbözik, a pubertás idején a fiúk artikulációs csatornája átlagosan $7,5 \mathrm{~mm}$-rel hosszabb, mint a lányoké, és a pubertást követően az átlagos különbség 12,9 mm. Ennek a nemek közötti különbségnek a hátterében elsősorban a garatüreg eltérő mértékủ növekedése áll, ami a férfiak esetében a gége „másodlagos leereszkedés”-éből adódik (Fitch-Giedd 1999). Mindezek a változások természetszerủleg hatnak a toldalékcső rezonátorsajátosságaira is.

Az egyes képzőszervek koordinációjának fejlődése sem egyenletes ütemű: például az állkapocsgesztusok korábban érnek (azaz válnak hasonlóbbá a felnőtt működéshez, a gesztus téri-idői kivitelezéséhez), mint az ajakmozgás, és még később rögzülnek a nyelvgesztusok, mivel a nyelvnek a beszédbeli kontrollálása komplexebb feladat, valamint azért is, mert a nyelv mozgása beszéd közben nem látható, így a nyelvmozgás 
felnőtt mintájának imitálása is nehezebb a gyermekek számára (Goffman 2015). Habár a gyermekek úgynevezett fonetikai jártassága, a beszédhangoknak az elvárásoknak megfelelő ejtésére való képesség 8 éves korra kialakul, a finommotorikus ügyesség még később is jelentősen fejlődik, és ez a folyamat tizenéves korra is kitolódik (VorperianKent 2007), ahogyan - mint fentebb írtuk - maga az artikulációs csatorna méretének és arányainak változása is. Felmerül mindezek alapján a kérdés, hogy miféle artikulációs tapasztalatra támaszkodhatunk a magánhangzók képzési jegyeinek tanításakor 5. és 9. osztályban.

Egy korábbi, különböző életkorú gyerekekkel végzett artikulációs kísérletünkben (Markó et al. 2019) gyermekek magánhangzóejtését vizsgáltuk ultrahangos nyelvkontúrok alapján. Az említett tanulmány elsősorban az ejtési variabilitásra fókuszált, míg itt az ultrahangos nyelvkontúrok alapján megragadható nyelvhelyzetet vizsgáljuk meg, elsősorban a függőleges dimenzióban. Természetesen egy ilyen jellegű vizsgálat nem adhat választ arra a kérdésre, hogy milyen fiziológiai visszacsatolás (biofeedback) áll rendelkezésre az adott beszélő esetében, pusztán azt tudjuk bemutatni, hogy milyen a nyelv helyzete a különféle magánhangzók esetében, valamint arról kaphatunk képet, hogy kirajzolódik-e a fenti táblázatok alapján elképzelt artikulációs elrendeződés.

\section{Módszertan}

\subsection{Ultrahang}

A modern artikulációs vizsgálati módszerek közül az ultrahang az egyik legkönynyebben alkalmazható gyermekek esetében is (Stone 2010), és jelenleg az ultrahang az egyik legelterjedtebb technológia a beszédkutató artikulációs laboratóriumokban (Wrench 2013). Az ultrahang a nyelv felszíni kontúrját teszi láthatóvá, úgy, hogy a rögzített képsorozatból ki kell nyerni a nyelv körvonalát ahhoz, hogy az adatokon további elemzéseket lehessen végezni. Ezt, annak érdekében, hogy a nyelv szájüregbeli helyzete meghatározható legyen, különféle módokon ki lehet egészíteni. Például ha az adatközlő folyadékot nyel a felvétel közben, a szájüregben lévő folyadékon áthaladnak az ultrahangnyalábok, és visszaverődnek a szájpadról, így ez a módszer alkalmas a szájpadkontúr kinyerésére (Epstein-Stone 2005). További viszonyítási alapot jelent a harapási sík felvétele (Scobbie et al. 2011). A harapási síkot úgy rögzíthetjük, hogy a két fogsor között egy merev lemezt helyezünk el, amelyre a kísérleti személy ráharap. A nyelvet a lemez aljához támasztva a nyelvkontúr kirajzolja a harapási síkot. A jelen vizsgálatban mind a nyelvkontúrokat, mind a szájpadkontúrt és a harapási síkot manuálisan rajzoltuk be az APIL szoftver segítségével (W2). Az elemzés során a nyelvkontúr és a szájpadkontúr egymáshoz legközelebbi pontjainak távolságát számszerűsítettük, így képeztük le a függőleges nyelvhelyzetet. 


\subsection{Anyag és módszer, kísérleti személyek}

A kísérlet anyagául három szótagos, jelentés nélküli hangsorok (logatomok) szolgáltak, amelynek szerkezete $\mathrm{V}_{1} \mathrm{C}_{1} \mathrm{~V}_{1} \mathrm{C}_{1} \mathrm{~V}_{1}$ volt, azaz egy hangsort ugyanazon magánhangzók és mássalhangzók alkottak. A hangsorok kilenc magyar köznyelvi magánhangzó-minőség ( $i, \ddot{u}, u, e ́, \ddot{o}, o, e, a, a ́$ ) és kilenc mássalhangzó (amelyek mindegyike zöngétlen zörejhang) kombinációjából álltak, így mindösszesen 81 hangsor szerepelt az eredeti kísérletben. A jelen tanulmányban ezekből csak a $\mathrm{V}_{1} p \mathrm{~V}_{1} p \mathrm{~V}_{1}$ logatomokban vizsgáljuk a felolvasott hangsorok második szótagbeli magánhangzóját. A $p$ kiválasztását az indokolta, hogy ennek a hangnak az ejtésekor a nyelv nem vesz részt aktívan a mássalhangzó akadályának megalkotásában, így a $p$ kontextusa várhatóan kevésbé befolyásolja a magánhangzók ejtése közben a nyelv helyzetét, mint a lingvális akadállyal képződő mássalhangzóké. A hangsorokat a kísérleti személyek képernyőről olvasták, a maguk számára kényelmes tempóban. A hangsorok random sorrendben szerepeltek, egyszerre egy volt látható a képernyőn. A 81 elemből álló sorozatot kétszer olvasták fel a résztvevők, a jelen tanulmányban csak az első bemondásokat elemezzük. A felvétel további körülményeire (műszaki adatok stb.), valamint az adatkinyerésre vonatkozóan lásd Markó és munkatársai (2019).

A jelen tanulmányban vizsgált adatok két kísérleti személy felvételéből származnak: egy 5. osztályos fiú (a felvétel időpontjában 11;5 éves volt) és egy 9. osztályos fiú (a felvétel időpontjában 14;8 éves volt) anyagából. A beszélők Budapesten élnek, sztenderd közeli nyelvváltozatot beszélnek. Minden résztvevő édesanyja felsőfokú végzettségű, az édesapák legalább középfokú végzettséggel rendelkeznek. A kísérleti személyek artikulációja normatív. A részvevőket és szüleiket előzetesen tájékoztattuk a kísérlet menetéről, a szülők az érvényes jogszabályoknak megfelelő hozzájárulási nyilatkozatot töltöttek ki.

A méretbeli eltérések illusztrálására bemutatjuk a szájpad, illetve a nyelv kontúrját és a harapási sík vonalát a két beszélő esetén (1. ábra). Az egyes részábrák a 9 magyar sztenderd nyelvi magánhangzó-minőséget mutatják a $\mathrm{Vp} \mathrm{Vp} \mathrm{V}$ szekvencia közepéről. Minden, az egyes magánhangzó-minőségekhez tartozó vonal egy-egy manuálisan berajzolt kontúrnak felel meg, amelyen bal oldalon található a nyelvgyök, jobb oldalon a nyelvhegy, a kettő között pedig a nyelv felső felülete. Az egyes ábrákon a legfelső vonal a szájpadot jelöli, a jobb alul látható egyenes pedig a harapási síkot. A skálák az eredeti ultrahangképhez vannak igazítva, azaz a $(0,0)$ koordinátájú pont az ultrahang kép bal alsó sarka, és a méretek mm-ben vannak feltüntetve, így a beszélö abszolút méreteit tükrözik. Látható, hogy a 14;8 éves fiú szájüregbeli méretei jóval nagyobbak (megjegyzendő, hogy nagyobbak az eredeti kísérletben részt vett felnőtt kontroll beszélőénél is, vö. Markó et al. 2019.), ahogyan az is, hogy a szájpad alakja, valamint a nyelv formája és láthatósága (a nyelvkontúr hossza) igen nagymértékben beszélö-, mi több, magánhangzófüggő. 


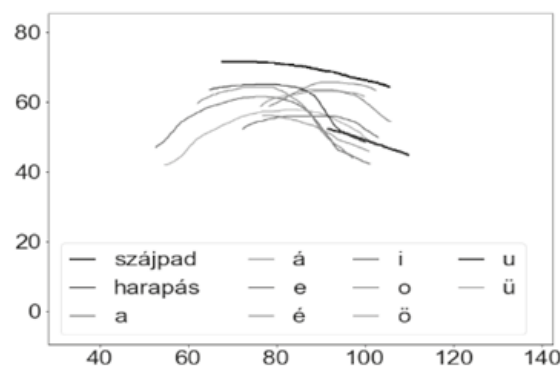

11;5 éves fiú

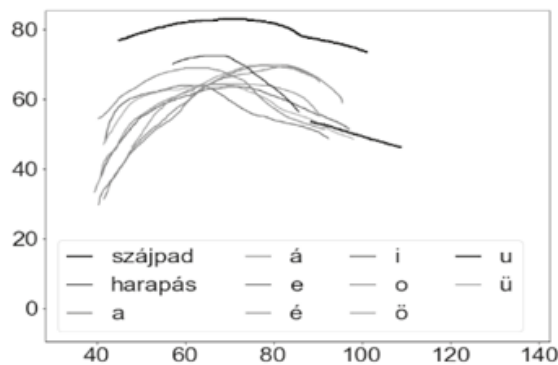

$14 ; 8$ éves fiú

1. ábra: A résztvevők nyelvkontúrja a 9 magánhangzó első ejtésekor a $\mathrm{V} p \mathrm{~V} p \mathrm{~V}$ szekvenciában (szürkeárnyalatú vonalak), a szájpad kontúrja (fekete vonal fent) és a harapási sík (fekete egyenes vonal a nyelvkontúrok mellett jobbra)

\section{Eredmények}

Habár egy-egy beszélő adatai alapján általánosítások nem fogalmazhatók meg, tekintettel arra, hogy a beszélőknek az ejtési mechanizmusokat befolyásoló fiziológiai sajátosságai általánosságban is igen eltérők, valamint arra, hogy a magánhangzóejtés maga is jelentős variabilitást mutat (ennek okait lásd a bevezetőben), egy-egy beszélő ejtésének vizsgálata is igen tanulságos annak illusztrálására, hogy a tankönyvi kategóriák megtanulása miért jelenthet nehézséget (a fiziológiai visszacsatolás problematikus voltán túlmenően). A 2. ábra három nyelvállásfok szerinti elrendezésben mutatja be a magyar 9 magánhangzó-minőségének ejtésekor látható nyelvkontúrokat az 5. osztályos és a 9. osztályos fiú bemondásában, a második magánhangzó közepén a $\mathrm{Vp} p \mathrm{~V} \mathrm{~V}$ szekvenciában.

A felső nyelvállású magánhangzók esetében jól elkülönül a hátul képzett $u$ és az elöl képzett $i$ és $\ddot{u}$ mindkét beszélő esetében, az elöl képzettek kontúrja viszonylag fedi egymást. A beszélők között a legnagyobb eltérés itt a szájtér és a nyelv méretkülönbségeiből adódó távolság a szájpad és a nyelv között.

A középső nyelvállásúak esetében mind a nyelv vízszintes, mind a nyelv függőleges helyzete nagyobb variabilitást mutat, mint azt a tankönyvi kategóriák alapján várnánk. Mindkét beszélőnél azt látjuk, hogy az $o$ és az é magasabb nyelvhelyzettel képződik, mint az $\ddot{o}$, valamint hogy a nyelv vízszintes helyzetét tekintve az $\ddot{o}$ nyelvkontúrja köztes pozíciót foglal el az $o$ és az é nyelvkontúrja között. Vagyis artikulációs alapon mind a nyelvállásfok, mind az elöl-hátul képzettség kategorizálása bizonytalan, a határok elmosódottak, és kérdéseket vetnek fel (például azt, hogy a lingvális jegyek mentén az ö és az é miért tartozik ugyanabba a csoportba). 
$\mathrm{mm}$

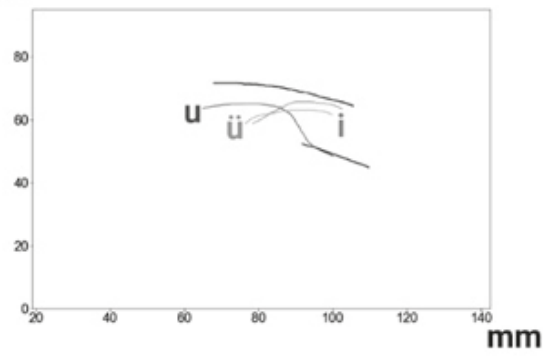

$\mathrm{mm}$

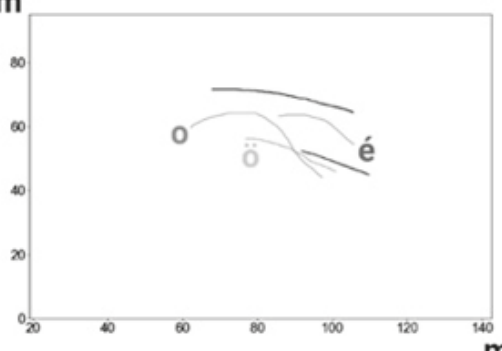

$\mathrm{mm}$

$\mathrm{mm}$

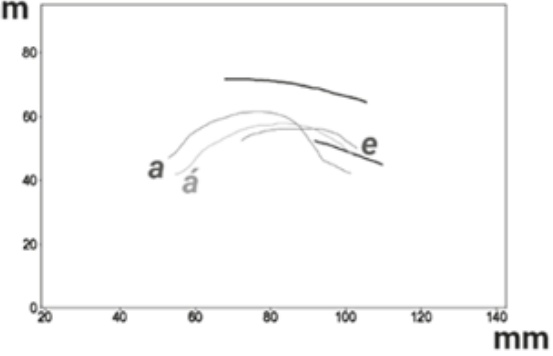

$\mathrm{mm}$

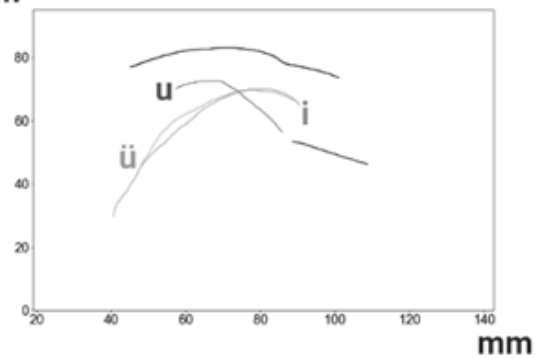

$\mathrm{mm}$

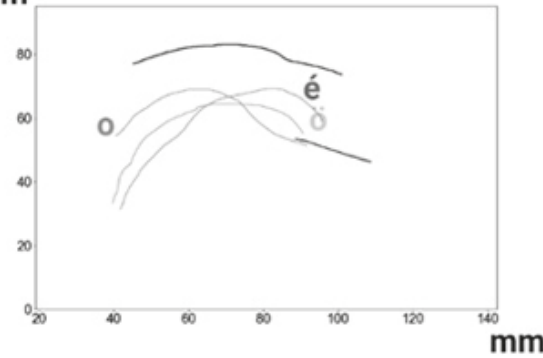

$\mathrm{mm}$

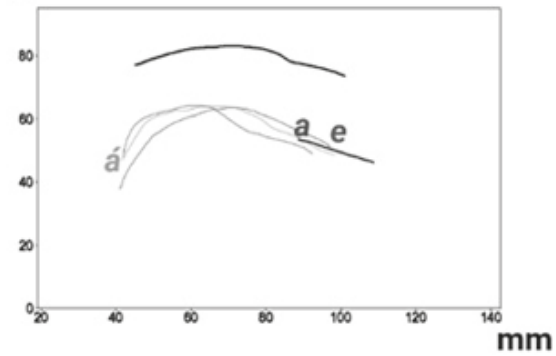

2. ábra: Az 5. osztályos (balra) és a 9. osztályos (jobbra) beszélő nyelvkontúrja a 9 magánhangzó első ejtésekor a $\mathrm{V} p \mathrm{~V} p \mathrm{~V}$ szekvenciában (szürkeárnyalatú vonalak), a szájpad kontúrja (fekete vonal fent) és a harapási sík (fekete egyenes vonal a nyelvkontúrok mellett): fent a felső nyelvállású, középen a középső nyelvállású, lent az alsó és legalsó nyelvállású magánhangzók

Az alsó és legalsó nyelvállásfok megkülönböztetésére lingvális alapon nem utalnak a nyelvkontúrok - az előbbit az $a$ és $e$, az utóbbit az á esetén várnánk megfigyelhetőnek a 9. osztályos tankönyvek nyomán (vö. 2. táblázat) (az állkapocs nyitódásának mértéke természetesen ettől még eltérhet az $a$, e és az á között, de ennek vizsgálatára a jelen módszer nem alkalmas, az állkapocsnyitódást pedig a tankönyvek nem is említik mint meghatározó tényezőt). A vízszintes nyelvhelyzetet tekintve az 5. osztályos beszélő esetében az á nyelvkontúrja köztes helyzetet foglal el az a és az e nyelvkontúrja között. 
A 9. osztályos beszélő esetében ez kevésbé látszik jól, mivel a nyelv hátulsó része szinte egymást átfedve látszik az a és az á nyelvkontúrján, de a nyelv formáját tekintve az á esetében az ív a szájtér közepén is magasan van még, ilyen értelemben előrébb képzettnek tartható, mint az $a$.

A 2. ábrán látható mintázatokat képezik le a nyelv függőleges helyzetének dimenziójában a nyelvkontúr és a szájpadkontúr egymáshoz legközelebbi pontjainak távolságadatai is (3. ábra).

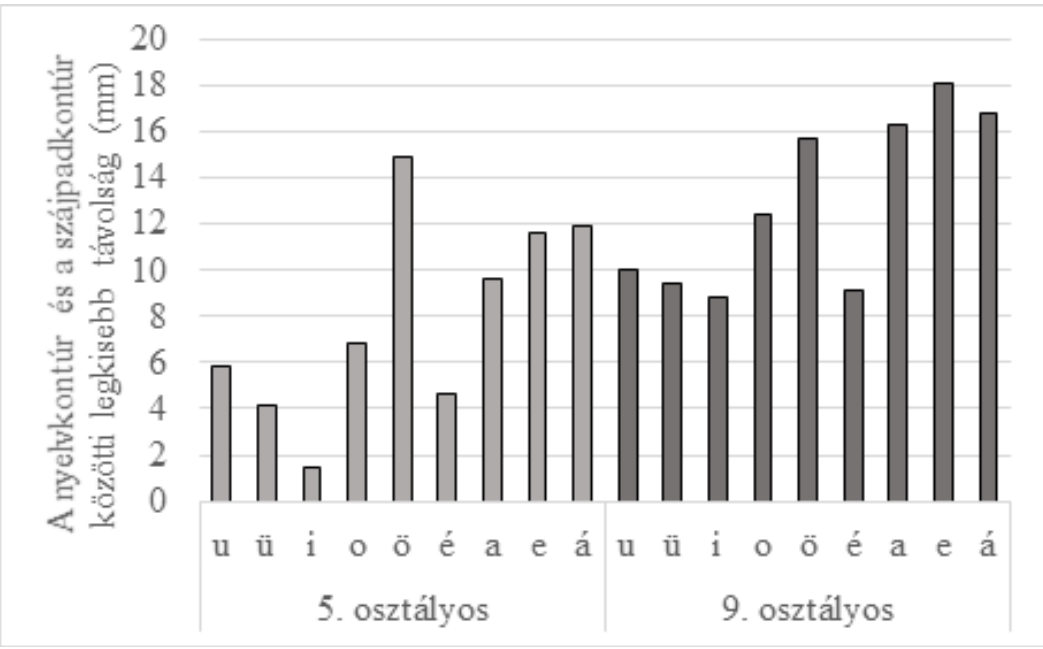

3. ábra: A nyelvkontúr és a szájpadkontúr egymáshoz legközelebbi pontjainak távolsága a két beszélő esetében, magánhangzónként

Ha feltételeznénk is, hogy a beszélő pontos fiziológiai visszacsatolással (biofeedback) rendelkezik a nyelvhelyzetről a különböző magánhangzók kiejtése közben (ami a bevezetőben írtak alapján kevéssé valószínű), és ezeket össze tudja hasonlítani egymással, majd ezen összevetések alapján képes kategóriákat elkülöníteni, a 2. és 3. ábra tanúsága szerint ezek a kategóriák a lingvális képzési jegyek esetében korántsem mutatnák azokat az elméleti kategóriák alapján csoportosítható magánhangzó-ejtési mintázatokat, amelyeket várnánk. Ehhez hozzáadódik még az életkorral összefüggésben a szájüreg méretbeli (és egyéb morfológiai) eltérése (például a szájpad alakja), valamint az egyének közötti és az egyénen belüli ejtési variancia is, amely ezeknek a kategóriáknak a határait igencsak elmosódottá teszi. 


\section{4. Összegzés és következtetések}

A nyelvkontúrok által megállapíthatóvá válik a nyelv helyzete a magánhangzó kiejtése közben. Ez képet ad arról, hogy a fiziológiai visszacsatolás milyen nyelvpozíciókból indulhat ki, de arról nem ad információt, hogy ez a visszacsatolás mennyire pontos. Mivel a magánhangzók nem akadályhangok, és a képzésük viszonylag statikus, feltételezhetjük, hogy a magánhangzók ejtése esetében a fiziológiai visszacsatolás bizonytalanabb, mint a mássalhangzók esetében. Ebből adódóan a magánhangzóejtés variábilisabb is lehet. Mindehhez hozzájárul még a toldalékcső méretváltozása, ami az iskolai oktatásban részt vevő gyermekek artikulációs tapasztalatainak további változatosságát idézi elő. Az artikulációs tapasztalat tehát nem (sokat) segít: egyrészt nagyon finom különbségeket kellene érzékelnünk, másrészt nagyok a fiziológiai eltérések (a felnőttek között is), ezért az artikulációs jellemzést nem lehet beszélők között általánosítani. A hangzók közötti különbségtételben nemcsak a nyelv helyzete, hanem a nyelv alakja és a szájpad alakja is meghatározó. Az oktatásban mindezek miatt a képzési jegyek elsajátítása számos nehézségbe ütközik.

A nyelvkontúrok vizsgálata további kérdéseket is felvet. Hol a határ az elöl és a hátul képzettek között? Hol a határ a felső, középső, alsó/legalsó nyelvállásúak között? A kérdések pedig oda vezetnek tovább, hogy adekvátak-e a tankönyvi és általában a hagyományos fonetikai kategóriák? A fonetikai hagyományban gyökerező elméleti konstruktumok részben leegyszerüsítők, az osztályozások artikulációs szempontból nem megalapozottak (hiszen bár képzési jegyekként utalunk rájuk, valójában nem pusztán artikulációs alapon alakultak ki). Továbbmenve, az a kérdés is megfogalmazható, hogy egyáltalán szükség van-e a képzési jegyek ilyetén bemutatására és tanítására az iskolai tananyag megértéséhez/feldolgozásához?

Ha áttekintjük a magyar magánhangzók hangtani viselkedésének mintázatait, arra a következtetésre jutunk, hogy a magánhangzók nyelvi „tulajdonságai”-nak nincs artikulációs vonatkozásuk a nyelvhasználatban, pontosabban az artikulációs megközelítés nélkül is leírhatók a magánhangzócsoportok viselkedésbeli hasonlóságai és különbségei. Az a „szokás”, hogy artikulációs jegyekkel írjuk le a magánhangzókat, a hagyományból ered, és vélhetőleg abból, hogy az artikulációs tapasztalat és a fiziológiai visszacsatolás alapján könnyebb(nek tűnik) lehorgonyozni ezeket. Ugyanakkor a tudományos megközelítések nem támasztják alá a magánhangzók esetében az artikulációs jegyekre alapuló leírást, ami azt jelenti, hogy tulajdonképpen bármilyen absztrakt fogalommal leírhatnánk, hogy bizonyos csoportjaik hasonlóan, mások eltérően viselkednek a magánhangzó-harmóniában (pl. kérek, karok), a magánhangzónyúlásban (pl. medve - medvét, fa - fát), a végszótagi tőmagánhangzó-rövidülésben (pl. egér - egeret, madár - madarat) stb. Nyelvi példákon keresztül könnyen megtapasztalható, hogy másképp viselkedik az $u, u ́, o, o ́, a, a$, mint a többi magánhangzó, ha a harmóniáról van szó, ahogyan az is belátható, hogy az $\ddot{u}, \ddot{u}, \ddot{o}$, ő eltérően viselkedik, mint az (ún. áttetsző) $i, i, e, e ́$. Ha ezeknek a csoportoknak az elnevezése nem sugallja a csoportbeli magánhangzók artikulációs hasonlóságát, csak a viselkedésbeli hasonlóságukra utal, akkor nem kell hosszas magyarázkodásba bocsátkoznunk például 
arra vonatkozóan sem, hogy hogy lehet fonológiailag (funkcionálisan, viselkedésében) egymás rövid hosszú párja az a és az á, amelyek artikulációs szempontból (megközelítéstől függően) alig vagy nem osztoznak közös tulajdonságokon.

Meg kellene fontolnunk, hogy a nyelvi funkciók és ne az artikuláció felől közelítsük a magánhangzókat a közoktatásban, mivel a nyelvhasználati tapasztalat sokkal hozzáférhetőbb és egyértelműbb, mint az artikulációs tapasztalat.

\section{Irodalom}

Ashby, Patricia 2011. Understanding phonetics. London: Hodder Education.

Antalné Szabó Ágnes - Raátz Judit 2010. Magyar nyelv és kommunikáció. Tankönyv a 9. évfolyam számára. Budapest: Nemzeti Tankönyvkiadó.

Antalné Szabó Ágnes - Raátz Judit 2012. Magyar nyelv és kommunikáció. Tankönyv az 5. évfolyam számára. Budapest: Oktatáskutató és Fejlesztő Intézet.

Epstein, Melissa A. - Stone, Maureen 2005. The tongue stops here: Ultrasound imaging of the palate. Journal of the Acoustical Society of America 118: 2128-2131. https://doi. org/10.1121/1.2031977

Esling, John H. 2005. There are no back vowels: The laryngeal articulator model. Canadian Journal of Linguistics 50: 13-44. https://doi.org/10.1353/cjl.2007.0007

Fitch, W. Tecumseh - Giedd, Jay 1999. Morphology and development of the human vocal tract: A study using magnetic resonance imaging. Journal of the Acoustical Society of America 106/3: 1511-1522. https://doi.org/10.1121/1.427148

Goffman, Lisa 2015. Effects of language on motor processes in development. In: Redford, Melissa A. (ed.): The handbook of speech production. Chichester: Wiley Blackwell. 555577. https://doi.org/10.1002/9781118584156.ch24

Gósy Mária - Bóna Judit 2014. Magánhangzók ejtése fiatalok és idősek spontán beszédében. Magyar Nyelv 110/2: 129-143.

IPA 1999 = International Phonetic Association 1999. Handbook of the International Phonetic Association: A guide to the use of the International Phonetic Alphabet. Cambridge: Cambridge University Press.

Markó Alexandra - Csapó Tamás Gábor - Deme Andrea - Gráczi Tekla Etelka - Bartók Márton 2019. Gyermekek lingvális artikulációjának variabilitása magánhangzós nyelvkontúrok alapján. In: Bóna Judit - Horváth Viktória (szerk.): Az anyanyelvelsajátitás folyamata hároméves kor után. Budapest: ELTE Eötvös Kiadó. 165-190.

Scobbie, James M. - Lawson, Eleanor - Cowen, Steve - Cleland, Joanne - Wrench, Alan A. 2011. A common co-ordinate system for mid-sagittal articulatory measurement. Working Paper WP-20. June 2011. Queen Margaret University, Edinburgh. https:// core.ac.uk/download/pdf/30321473.pdf.

Seikel, J. Anthony - King, Douglas W. - Drumright, David G. 2010. Anatomy \& physiology for speech, language and hearing. Fourth edition. Delmar: Cengage Learning. 
Stevens, Kenneth N. 1998. Acoustic phonetics. Cambridge, London: The MIT Press.

Stone, Maureen 2010. Laboratory techniques for investigating speech articulation. In:

Hardcastle, William J. - Laver, John - Gibbon, Fiona E. (eds.): The handbook of phonetic sciences. Second edition. Oxford: Wiley-Blackwell. 9-38.

https://doi.org/10.1002/9781444317251.ch1

Vorperian, Houri K. - Kent, Ray D. 2007. Vowel acoustic space development in children: A synthesis of acoustic and anatomic data. Journal of Speech, Language, and Hearing Research 50: 1510-1545.

https://doi.org/10.1044/1092-4388(2007/104)

Wrench, Alan 2013. Ultrasound speech analysis: State of the art. Elöadás az Ultrafest VI konferencián. http://materials.articulateinstruments.com/Technical/State_of_Art.ppt.

\section{Internetes hivatkozások}

W1 = https://en.wikipedia.org/wiki/IPA_vowel_chart_with_audio (2020. 04. 22.)

W2 = APIL tracing tool https://github.com/arizona-phonological-imaging-lab/apil-web (2019. 07. 21.) 